\title{
Influence of Height of Cane and Leaf Stage at Time of Sampling on Leaf-Nutrient Content of Sugarcane
}

\author{
G. Samuels, P. Landrau, Jr., and S. Alers-Alers ${ }^{1}$
}

\section{INTRODUCTION}

To anyone working on either plant or soil analyses the importance of a representative sample is well-known. It is usually expressed in the saying, "No method of soil or plant analysis is any better than the sample taken". The question often confronts workers using foliar-diagnostic methods as to what cane should be taken in the field at sampling time.

From the side of the road a cane field may appear to the layman as rather uniform in height and growth. Yet this cane field is made up of a rather heterogeneous population as regards cane height and growth. The old or original plant tillers grow side by side with intermediate and young plant tillers. Even when cane heights are about the same to the eye, some canes will have a few more leaves on them than others.

Thus, regardless of the date chosen to sample the leaves of the sugarcane, it is problematical whether your sample is a representative one or is influenced by such factors as cane height or leaf stage. The objective of the work herein reported was to determine whether, at a given time of leaf sampling, the height of the cane or its leaf stage would influence the nutrient content (N-P-K) of the leaf.

\section{PROCEDURE}

The leaf material used in this study came from a sugarcane fertilizer experiment described in an earlier paper (2) ${ }^{2}$. The plant cane of a planting of B. 41227 and M. 336 grown on a Vega Baja silty clay at the Agricultural Experiment Station at Río Piedras was used. The experiment was planted on June 18, 1954.

Leaf samples for determining the influence of the height of the cane at sampling time on the leaf-nutrient content were taken at a cane age of 3 months from variety B. 41227 . Leaf samples were chosen from canes measuring about 12 inches as young tillers, 24 inches as intermediate tillers, and 36 inches as original plant tillers. The measurements were made from the first visible leaf ligule to the soil line. Leaf samples were taken from the various fertilizer plots using the three class measurements for height.

1 Agronomist, former Associate Agronomist, and Research Assistant in Agronomy, respectively, Agricultural Experiment Station, University of Puerto Rico, Río Piedras, P. R.

2 Italic numbers in parentheses refer to Literature Cited, p. 15. 
Both varieties, B. 41227 and M. 336, were used in the study on the influence of the leaf stage on the leaf-nutrient content. Leaf stage was defined herein as the number of fully developed green leaves present on the plant at time of sampling. Numbering began with the first fully developed leaf. The rolled spindle leaf was not counted. Leaf samples were taken at 7, 9, 11 , and 13 weeks at respective leaf stages of 6 and 8,8 and 10, 10 and 12, and 12 and 14 leaves.

The entire leaf was utilized for all leaf samples taken. The procedures for the preparation of the leaf samples and the chemical analyses are given in a previous publication (1).

\section{RESULTS}

\section{Cane Heights}

Variations in the height of the cane in a field being sampled do not seem to have any marked influence on the nitrogen or potassium content of the leaf sample (table 1). The variation in the height of cane at time of sampling influenced leaf-phosphorus values in the no-phosphorus treatment only. There was an increase in leaf-phosphorus values with increase in cane height. In general, it may be said that leaf-nutrient values did not tend to change as the cane height increased, except for phosphorus.

There were significant differences in leaf-nutrient values for each respective element with increased application of that fertilizer element to the soil (table 1).

It appears that variations in cane height at sampling time do not have any marked influence on leaf-nutrient values. Care should be taken, however, to avoid selecting as samples plants that are not truly representative of the field sampled. Possibly short young tillers are more sensitive indicators of phosphorus deficiencies than taller more mature tillers.

\section{Leaf Stage}

Except in a few cases the leaf stage, or number of leaves present at time of leaf sampling, involving a simultaneous variation in age of 4 weeks, i.e., from 7 to 11 weeks of age, had no significant influence on the nutrient content of the sugarcane leaf (table 2). When leaf samples were taken at 9 weeks, at a leaf stage of from 8 to 10 leaves, there was a significant difference in nitrogen for M. 336 . That is to say cane with only 8 leaves had a significantly lower leaf-nitrogen content than did cane with 10 . This was the only sampling which showed differences. Otherwise there were no significant differences in leaf-nitrogen, regardless of leaf stage at time of sampling.

In the 9-week sample, where 8 and 10 leaves were present on the cane, there was a significant difference between leaf-phosphorus values at differ- 
TaBle 1.-The influence of the height of sugarcane at time of leaf sampling on its leaf-nutrient content

\begin{tabular}{|c|c|c|c|c|}
\hline \multirow{2}{*}{$\begin{array}{l}\text { Height of cane } \\
\text { (incles) }\end{array}$} & \multicolumn{4}{|c|}{$\begin{array}{l}\text { Leaf-nutrient value on a dry-weight basis for fertilizer treatment } \\
\text { level indicated }\end{array}$} \\
\hline & 0 & 1 & 2 & $\begin{array}{l}\text { Mean of all } \\
\text { levels }\end{array}$ \\
\hline \multicolumn{5}{|c|}{ Nitrogen $(N)$} \\
\hline $\begin{array}{l}12 \\
24 \\
36 \\
\quad \text { Mean of all heights }{ }^{2}\end{array}$ & $\begin{array}{c}\text { Percent } \\
0.99 \\
1.17 \\
1.15 \\
1.10\end{array}$ & $\begin{array}{c}\text { Percent } \\
1.39 \\
1.45 \\
1.29 \\
1.38\end{array}$ & $\begin{array}{c}\text { Percent } \\
1.55 \\
1.57 \\
1.40 \\
1.51\end{array}$ & $\begin{array}{l}\text { Percent } \\
1.31 \\
1.40 \\
1.28\end{array}$ \\
\hline $\begin{array}{l}\text { L.S.D. } 5 \text { percent } \\
\text { L.S.D. } 1 \text { percent }\end{array}$ & $\begin{array}{r}0.21 \\
.29\end{array}$ & $\begin{array}{r}0.21 \\
.29\end{array}$ & $\begin{array}{r}0.21 \\
.29\end{array}$ & $\begin{array}{r}0.13 \\
.19\end{array}$ \\
\hline \multicolumn{5}{|c|}{ Phosphorus $(P)$} \\
\hline $\begin{array}{l}12 \\
24 \\
36 \\
\quad \text { Mean of all heights } 2\end{array}$ & $\begin{array}{r}0.13 \\
.16 \\
.18 \\
.15\end{array}$ & $\begin{array}{r}0.15 \\
.15 \\
.17 \\
.16\end{array}$ & $\begin{array}{r}0.18 \\
.18 \\
.19 \\
.18\end{array}$ & $\begin{array}{r}0.15 \\
.16 \\
.18\end{array}$ \\
\hline $\begin{array}{l}\text { L.S.D. } 5 \text { percent } \\
\text { L.S.D. } 1 \text { percent }\end{array}$ & $\begin{array}{r}0.024 \\
.033\end{array}$ & $\begin{array}{r}0.024 \\
.033\end{array}$ & $\begin{array}{r}0.024 \\
.033\end{array}$ & $\begin{array}{r}0.017 \\
.024\end{array}$ \\
\hline \multicolumn{5}{|c|}{ Potassium $(K)$} \\
\hline $\begin{array}{l}12 \\
24 \\
36 \\
\quad \text { Mean of all heights }{ }^{2}\end{array}$ & $\begin{array}{r}0.80 \\
.74 \\
.82 \\
.79\end{array}$ & $\begin{array}{l}1.32 \\
1.24 \\
1.41 \\
1.33\end{array}$ & $\begin{array}{l}1.46 \\
1.53 \\
1.75 \\
1.58\end{array}$ & $\begin{array}{l}1.19 \\
1.17 \\
1.33\end{array}$ \\
\hline $\begin{array}{l}\text { L.S.D. } 5 \text { percent } \\
\text { L.S.D. } 1 \text { percent }\end{array}$ & $\begin{array}{r}0.29 \\
.40\end{array}$ & $\begin{array}{r}0.29 \\
.40\end{array}$ & $\begin{array}{r}0.29 \\
.40\end{array}$ & $\begin{array}{r}0.19 \\
.26\end{array}$ \\
\hline
\end{tabular}

1 The following quantities of fertilizer in pounds per acre were used for the indisated units.

\begin{tabular}{c|r|r|c|c|c|c|c|c|c}
\hline \multirow{3}{*}{ Fertilizer units } & \multicolumn{3}{|c|}{ Nitrogen treatments } & \multicolumn{2}{|c|}{ Phosphorus treatments } & \multicolumn{2}{c|}{ Potassium treatments } \\
\cline { 2 - 8 } & $\mathrm{N}$ & $\mathrm{P}_{2} \mathrm{O}_{5}$ & $\mathrm{~K}_{2} \mathrm{O}$ & $\mathrm{N}$ & $\mathrm{P}_{2} \mathrm{O}_{3}$ & $\mathrm{~K}_{2} \mathrm{O}$ & $\mathrm{N}$ & $\mathrm{P}_{2} \mathrm{O}_{5}$ & $\mathrm{~K}_{2} \mathrm{O}$ \\
\hline 0 & 0 & 300 & 300 & 300 & 0 & 300 & 300 & 300 & 0 \\
1 & 150 & 300 & 300 & 300 & 150 & 300 & 300 & 300 & 150 \\
2 & 300 & 300 & 300 & 300 & 300 & 300 & 300 & 300 & 300 \\
\hline \hline
\end{tabular}

2 For the comparison of the mean of all heights for the indicated nutrient:

L.S.D. 5-percent level

L.S.D. 1-percent level

\begin{tabular}{|c|c|c} 
Nitrogen (N) & Phosphorus (P) & Potassium (K) \\
\cline { 1 - 2 } 0.12 & 0.011 & 0.16 \\
.16 & .015 & .22 \\
\hline
\end{tabular}


ent leaf stages. However, the effect of leaf stage is not at all clear because the leaf phosphorus was significantly higher in the 10-leaf stage of B. 41227 than in the 8-leaf one. But the reverse was true of M. 336. No significant influence of leaf stage was found for the other three sampling ages.

No differences in leaf-potassium were found at different leaf stages at any of the times of samplings tried.

TABLE 2.-The influence of the sugarcane leaf stage at time of leaf sampling on its leaf-nutrient content (percent)

\begin{tabular}{|c|c|c|c|c|c|c|}
\hline \multirow{3}{*}{ Leaf stage' } & \multicolumn{6}{|c|}{ Leaf-nutrient value on a dry-weight bas $s$ for element indicated- } \\
\hline & \multicolumn{2}{|c|}{ Nitrogen $(\mathrm{N})$} & \multicolumn{2}{|c|}{ Phosphorus (P) } & \multicolumn{2}{|c|}{ Potassium (K) } \\
\hline & B. 41227 & M. 336 & B. 41227 & M. 336 & B. 41227 & M. 336 \\
\hline 6 & 2.20 & 2.29 & 0.22 & 0.22 & 1.34 & 1.48 \\
\hline 8 & 2.15 & 2.35 & .22 & .22 & 1.40 & 1.55 \\
\hline L.S.D. 5 percent & .137 & .119 & .016 & .017 & .114 & .114 \\
\hline L.S.D. 1 percent & .187 & .163 & .022 & .023 & .156 & .156 \\
\hline 8 & 1.69 & 1.57 & .19 & .20 & 1.60 & 1.71 \\
\hline 10 & 1.71 & 1.75 & .23 & .18 & 1.68 & 1.80 \\
\hline L.S.D. 5 percent & .100 & .131 & .013 & .013 & .185 & .196 \\
\hline L.S.D. 1 percent & .136 & .179 & .018 & .018 & .252 & .267 \\
\hline 10 & 1.33 & 1.33 & .19 & .19 & 1.51 & 1.57 \\
\hline 12 & 1.30 & 1.32 & .20 & .19 & 1.41 & 1.60 \\
\hline L.S.D. 5 percent & .086 & .081 & .013 & .010 & .178 & .113 \\
\hline L.S.D. 1 percent & .118 & .110 & .018 & .013 & .242 & .154 \\
\hline 12 & 1.18 & 1.36 & .19 & .20 & 1.34 & 1.80 \\
\hline 14 & 1.20 & 1.36 & .18 & .20 & 1.40 & 1.77 \\
\hline L.S.D. 5 percent & .091 & .088 & .011 & .014 & .158 & .138 \\
\hline L.S.D. 1 percent & .125 & .120 & .015 & .019 & .215 & .188 \\
\hline
\end{tabular}

3 The 6-8 leaf stage was sampled 7 weeks after the cane was planted, the 8-10 leaf stage 9, the 10-12 leaf stage 11 , and the 12-14 leaf stage at 13 weeks.

There was a general decrease in leaf-nutrient content as the age of the leaf sample increased in the various leaf stages. This decrease of leaf-nutrient content with age had been previously found to be true in general for sugarcane, as reported in detail in a previous publication ( 8 ).

For practical purposes it appears that no special consideration need be given to the leaf stage at time of leaf sampling. This is especially true for leaf sampling at such an early age as 3 months, as recommended for use in Puerto Rico (1). As can be seen from table 2, leaf samples taken at 13 weeks, with a leaf stage of 12 to 14 leaves, showed no significant variation in leafnutrient content with leaf stage. 


\section{SUMMARY}

Leaf samples of sugarcane were taken from a fertilizer experiment at Río Piedras with varieties B. 41227 and M. 336 to determine whether the height of cane or the number of leaves present at leaf-sampling time influenced the nutrient content of the leaf sample. It was found that:

1. There was no significant difference in leaf nitrogen or potassium from cane tillers aged 3 months with heights of 12,24 , and 36 inches.

2. Variations in cane height at time of sampling did influence leaf-phosphorus values; there were increases in cane height.

3. The number of leaves present at time of sampling (7-13 weeks) did not influence leaf-nutrient values in general, except for nitrogen and phosphorus at 9 weeks of age. Here the trends of this influence with the two varieties studied were contrary.

\section{RESUMEN}

Se tomaron muestras de hojas de caña de azúcar de un experimento sobre abonos llevado a cabo en Río Piedras con las variedades B. 41227 y M. 336 para determinar si la altura de la caña o el número de hojas presente, al tiempo de tomar las muestras, influía sobre el contenido de nutrientes en la hoja. Los resultados demostraron lo siguiente:

1. En una caña de 3 meses no hubo diferencia significativa en el contenido de nitrógeno o de potasa en la hoja de los tallos a las alturas de 12,24 y 36 pulgadas.

2. En cuanto al contenido de fósforo, las variaciones en la altura de la caña, al tiempo de tomar las muestras, influyó sobre los valores de este elemento en la hoja, aumentándose el fósforo según era mayor la altura de la caña.

3. El número de hojas presente, al tiempo de la toma de las muestras, no influyo, en términos generales, sobre los valores de los nutrientes en la hoja, con excepción del nitrógeno y el fósforo a la edad de 9 semanas. En el último caso, la tendencia de esta influencia en las dos variedades que se estudiaron estuvo en relación opuesta.

\section{LITERATURE CITED}

1. Capó, B. G., Samuels, G., Landrau, P., Jr., Alers-Alers, S., and Riera, A., The Method of Foliar Diagnosis as Applied to Sugarcane, Agr. Exp. Sta. Univ. P. R., Bul. 123, Feb. 1955.

2. Landrau, P., Jr., Samuels, G., and Alers-Alers, S., The response of two sugarcane varieties to fertilizers at Río Piedras, 1954-57, J. Agr. Univ. P.R. 43 (2) 73-88, 1959.

3. Samuels, G., Influence of the age of sugarcane on its leaf-nutrient value, J. Agr. Univ. P.R. 43 (3) 159-70, 1959. 